Goldschmidt 2021 Abstract

https://doi.org/10.7185/gold2021.3542

\section{Thermodynamics for clay minerals: calculation tools for estimating thermodynamic properties}

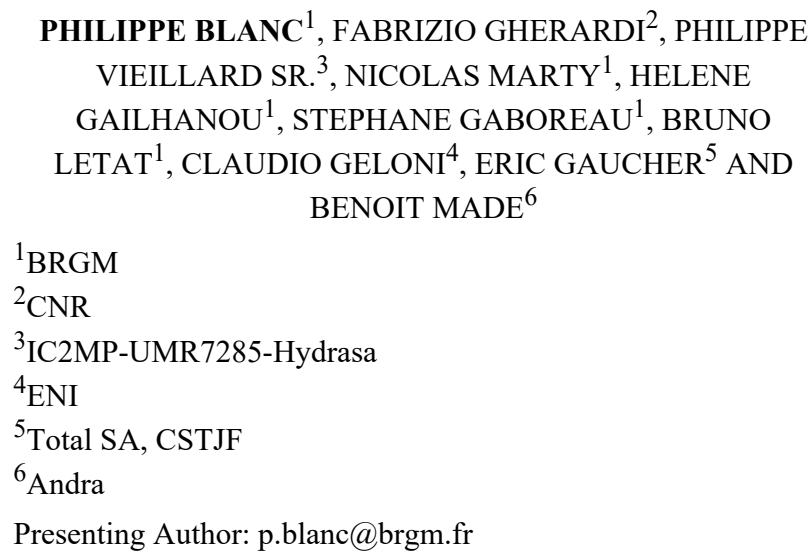

Presenting Author: p.blanc@brgm.fr

Thermodynamics for clay minerals: calculation tools for estimating thermodynamic properties

1. Blanc ${ }^{1 *}$, Gherardi F. ${ }^{2}$, Vieillard P. ${ }^{3}$, Marty N.C.M. ${ }^{1}$, Gailhanou H. ${ }^{1}$, Gaboreau S. ${ }^{1}$, Letat B. ${ }^{1}$, Geloni C. ${ }^{4}$, Gaucher E.C. ${ }^{5}$, Madé B. ${ }^{6}$

${ }^{1}$ BRGM, 3 Avenue Claude Guillemin, 45060 Orléans Cedex 2, France (*correspondance: p.blanc@brgm.fr)

${ }^{2}$ IGG - CNR, Via G. Moruzzi, 56124 Pisa, Italy

${ }^{3}$ CNRS-IC2MP-UMR-7285 Hydrasa, 5 av. Albert Turpain, 86073 Poitiers Cedex, France

${ }^{4}$ Geological Laboratories, ENI S.p.A., San Donato Milanese, Italy.

${ }^{5}$ TOTAL S.A., Avenue Larribau, 64018 Pau, France

${ }^{6}$ ANDRA, 92298 Châtenay-Malabry, France.

Two computing tools, ClayTherm and ISTherm, have been developed to estimate the thermodynamic properties of both anhydrous and hydrated clay minerals (ClayTherm), and of illite/smectite (I/S) mineral series (ISTherm). The first computing tool, ClayTherm, is devoted to thermodynamic property estimates for clay minerals. It combines several previously published estimation models $[1,2]$, including hydration aspects. It proposes an improved consistency among the different estimate methods and an interface allowing simplifying the calculation process for a wide range of clay mineral compositions. Verification is provided, against a set of solubility data, selected from previous literature.

A second application ISTherm was subsequently developed based on the first development. It focuses on the smectite-to-illite transformation, and it provides estimates for the thermodynamic properties of a series of illite/smectite (I/S) interstratified minerals. The estimates for a whole composition serie can be provided based on the composition of a single I/S sample. In the development process, the thermodynamic functions from ClayTherm have been supplemented with mixing energies extracted from the literature. A verification is proposed, considering the case of a natural I/S hydrothermal series from the
Shinzan geothermal field (Japan). Phase realations and illitisation rates are found to be in agreement with previous mineralogical observations and solution chemical analyses.

[1] P. Vieillard, H. Gailhanou, A. Lassin, P. Blanc, E. Bloch, R. Denoyel, S. Gaboreau, C.I. Fialips, B. Madé, Applied geochemistry, (2019), 110, 104423.

[2] P. Blanc, P. Vieillard, H. Gailhanou, S. Gaboreau, E.C. Gaucher, C.I. Fialips, B. Madé, E. Giffaut, American Journal of Science, 315 (2015) 734-780. 